\title{
Zoothentic evaluation of tilapian alevines feed fed with kefir
}

\author{
Avaliação zootécnica de alevinos de tilápia alimentadas com kefir \\ Evaluación zootécnica de alevines de tilapia alimentados con kefir
}

\author{
Alessandra Maria da Silva \\ ORCID: https://orcid.org/0000-0002-6369-7672 \\ Universidade José do Rosário Vellano, Brazil \\ E-mail: alessandra_li26@hotmail.com \\ Angélica Cristina de Souza \\ ORCID: https://orcid.org/0000-0002-4013-6354 \\ Universidade Federal de Lavras, Brazil \\ E-mail: angelicacsouza.acs@gmail.com \\ Diego Magno Assis \\ ORCID: https://orcid.org/0000-0002-6252-661X \\ Condomínio Barão de Mauá, Brazil \\ E-mail: diego.assis@bruker.com \\ Ana Carolina Ortegal Almeida \\ ORCID: https://orcid.org/0000-0003-3996-669X \\ Universidade José do Rosário Vellano, Brazil \\ E-mail: ana.almeida@unifenas.br \\ Clara de Mello Silva Oliveira \\ ORCID: https://orcid.org/0000-0001-7850-6579 \\ Universidade José do Rosário Vellano, Brazil \\ E-mail: mellodeca@gmail.com \\ Luiz Antônio Alves Pereira Junior \\ ORCID: https://orcid.org/0000-0003-4031-2036 \\ Universidade José do Rosário Vellano, Brazil \\ E-mail: juninhorodriguesalves@ hotmail.com \\ Maria das Graças de Souza Carvalho \\ ORCID: https://orcid.org/0000-0001-8726-6327 \\ Universidade José do Rosário Vellano, Brazil \\ E-mail: mariah_roots@hotmail.com \\ Gérsika Bitencourt Santos \\ ORCID: https://orcid.org/0000-0003-0849-2786 \\ Universidade José do Rosário Vellano, Brazil \\ E-mail: gersika.santos@unifenas.br \\ Pedro Ivo Sodré Amaral \\ ORCID: https://orcid.org/0000-0002-2366-2088 \\ Universidade José do Rosário Vellano, Brazil \\ E-mail: pedro.amaral@unifenas.br \\ Wilson Roberto Mesquita Oliveira \\ ORCID: https://orcid.org/0000-0002-5564-4757 \\ Universidade José do Rosário Vellano, Brazil \\ E-mail: wilson.oliveira@unifenas.br \\ José Antonio Dias Garcia \\ ORCID: https://orcid.org/0000-0002-4024-3045 \\ Universidade José do Rosário Vellano, Brazil \\ E-mail: jadiasgarcia@gmail.com \\ Nelma de Mello Silva Oliveira \\ ORCID: https://orcid.org/0000-0002-1114-2018 \\ Universidade José do Rosário Vellano, Brazil \\ E-mail: nelma.oliveira@unifenas.br
}

\begin{abstract}
Introduction: Probiotics have variable microbiological composition, which results in distinct by-product profiles and consequent beneficial probiotic action for animals. Objective: it aimed to characterize the microorganisms present in kefir samples and those stabilized in commercial rations for consumption in fish farming and to evaluate the result in a zootechnical profile. Methodology: The microbial quantification process of kefir grown in milk, brown sugar and feed mixed with grains and fermented solutions was carried out by decimal dilutions, plated in De Man Rogosa and Sharpe
\end{abstract}


(MRS) medium for Lactobacillus, "Brain Heart Infusion", (BHI) for global bacterial count, glucose Sabouraud for yeasts and the NMP technique for coliforms at $35^{\circ} \mathrm{C}$ and $45^{\circ} \mathrm{C}$ and $\mathrm{EMB}$ for Escherichia coli. For the identification of the genus and species, mass spectrometry (Mald Tof) was used. Treatments with milk, grains and water with brown sugar were used, with kefir in the dose of $4 \%$ of the different forms for each kilogram of feed. Results: These treatments indicate changes in the results that are statistically significant in relation to the total size, partial size and width. As for weight, it showed statistically significant results only after 15 days of treatment. Conclusion: The experimental conditions used and the proportion of $4 \%$ of the feed did not influence the parameters of the zootechnical profile of the animals.

Keywords: Oreochromis niloticus; Probiotics; Aquaculture.

\section{Resumo}

Introdução: Os probióticos possuem composição microbiológica variável, o que resulta em perfis de subprodutos distintos e conseqüente ação probiótica benéfica para os animais. Objetivo: caracterizar os microrganismos presentes em amostras de kefir e aqueles estabilizados em rações comerciais para consumo em piscicultura e avaliar o resultado em um perfil zootécnico. Metodologia: O processo de quantificação microbiana do kefir cultivado em leite, açúcar mascavo e ração misturado com grãos e soluções fermentadas foi realizado por diluições decimais, plaqueadas em meio De Man Rogosa e Sharpe (MRS) para Lactobacillus, "Brain Heart Infusion”, (BHI) para contagem bacteriana global, glicose Sabouraud para leveduras e a técnica de NMP para coliformes a $35^{\circ} \mathrm{C}$ e $45^{\circ} \mathrm{C}$ e EMB para Escherichia coli. Para a identificação do gênero e espécie, foi utilizada a espectrometria de massa (Mald Tof). Foram utilizados tratamentos com leite, grãos e água com açúcar mascavo, com kefir na dose de $4 \%$ das diferentes formas para cada quilograma de ração. Resultados: Esses tratamentos indicam mudanças nos resultados que são estatisticamente significativas em relação ao tamanho total, tamanho parcial e largura. Quanto ao peso, apresentou resultados estatisticamente significantes apenas aos 15 dias de tratamento. Conclusão: As condições experimentais utilizadas e a proporção de $4 \%$ da ração não influenciaram os parâmetros do perfil zootécnico dos animais.

Palavras-chave: Oreochromis niloticus; Probióticos; Aquicultura.

\section{Resumen}

Introducción: Los probióticos tienen una composición microbiológica variable, lo que da como resultado distintos perfiles de subproductos y la consiguiente acción probiótica beneficiosa para los animales. Objetivo: tuvo como objetivo caracterizar los microorganismos presentes en muestras de kéfir y estabilizados en raciones comerciales para consumo en piscicultura y evaluar el resultado en un perfil zootécnico. Metodología: El proceso de cuantificación microbiana de kéfir cultivado en leche, panela y pienso mezclado con granos y soluciones fermentadas se realizó mediante diluciones decimales, sembrado en medio De Man Rogosa y Sharpe (MRS) para Lactobacillus, "Brain Heart Infusion", ( BHI) para recuento bacteriano global, glucosa Sabouraud para levaduras y la técnica NMP para coliformes a $35^{\circ} \mathrm{C}$ y $45^{\circ} \mathrm{C}$ y EMB para Escherichia coli. Para la identificación del género y la especie se utilizó espectrometría de masas (Mald Tof). Se utilizaron tratamientos con leche, cereales y agua con panela, con kéfir en la dosis del $4 \%$ de las diferentes formas por cada kilogramo de pienso. Resultados: Estos tratamientos indican cambios en los resultados que son estadísticamente significativos en relación al tamaño total, tamaño parcial y ancho. En cuanto al peso, mostró resultados estadísticamente significativos solo después de 15 días de tratamiento. Conclusión: Las condiciones experimentales utilizadas y la proporción del $4 \%$ del pienso no influyeron en los parámetros del perfil zootécnico de los animales.

Palabras clave: Oreochromis niloticus; Probióticos; Acuicultura.

\section{Introduction}

Fish production is the fastest growing area of animal production in Brazil and in the world. This is due to high demand for the consumption of fish meat that is constantly growing. However, fish production, besides requiring a lot of care, requires specific and practical knowledge (Oenning, 2013).

Over the past two decades, the development of Nile tilapia (Oreochromis niloticus) cultivation has drastically increased the world's production of freshwater fish (Fao, 2012). In Brazil, production reached 722,560 tons of fish farmed in 2018, a growth of $4.5 \%$ over the 691,700 tons of the previous year. Data is taken from the national survey of the Brazilian Fish Association (PeixeBR, 2019). 
"Nile Tilapia" is native to African countries, but it is the most widely cultivated tilapia species in the world. This is because they show fast growth, are of great rusticity, favorable reproduction, easy management, high-quality meat and, mainly, good selling market (Macari, 2007). As a species that offers pathological resistance and low oxygen levels, Nile Tilapia is suitable for subsistence fish farming, with a rapid increase in cultivation in developing countries (Cyrino et al., 2010).

Tilapia production in 2018 in Brazil was of 400,280 tons, 11.9\% higher than the previous year (357,639 t). With this performance, the species represents 55.4\% of the total production of farmed fish according to the Brazilian Fish Association (PeixeBR, 2019).

Over the years, the aquaculture sector has undergone a radical change to meet rising demand. Production is maximized through intensification with the addition of commercial diets, growth promoters, antibiotics, and various other additives. Applying these measures leads to high production beyond any doubt. However, there is a concern factor that is the routine use of these products, which can cause serious complications, endangering their sustainability (Panigrahi \& Azad, 2007).

Another problem faced by aquaculture occurs during fish transport procedures, given that, in this process, they are exposed to unpleasant stimuli that cause their immune capacity to decrease (Silveira, Logato \& Pontes, 2009).

In aquaculture practices, probiotics have been used for a long time, but in recent years have become an integral part of crop treatment for improved growth and disease resistance. This strategy offers numerous advantages in overcoming the limitations and side effects of antibiotics and other medicines, as well as promoting high production through enhanced and prevented disease growth (Sahu et al., 2008).

Probiotics are products based on living microorganisms which, when administered in adequate amounts, confer consumer health benefits by improving the balance of the gut microbiota. This microbiota colonizes the host organism and multiplies, inhibiting the proliferation of harmful agents to the intestinal mucosa lining epithelium (Nayak, 2010; Mello et al., 2013).

This protective action is due to probiotic bacteria producing important digestive vitamins and enzymes, as well as providing minerals and trace elements needed by the animal (Holzapfel et al., 1998).

Probiotics act positively in the gut of aquatic animals, providing benefits in the structure of microvilli and increased surface absorption (Mello et al., 2013). However, in a study by Ferreira et al. (2014), Bacillus spp-based probiotics were added to the feed to improve intestinal absorption and transport water of Tambaqui (Colossoma macropomum), so that transport stress did not affect the immunological capacity of the fish, however, changes were not observed in the intestinal weight, height, and length of Tambaqui juveniles, nor interference in the immune capacity.

One probiotic that has been doing well and becoming popular in food is kefir. This is a fermented drink of milk or water with brown sugar, which demonstrates, through its biochemical and microbiological composition, act as functional foods, promoting the balance of intestinal microbiota and bringing benefits to the body as a whole. Because of positive results as a probiotic, it has also been incorporated into research on diets of farmed animals (Lee Salminem, 1995; Güven, Güven \& Gülmez, 2003; Rodrigues et al., 2005).

The microbiological composition of kefir includes lactic acid bacteria, yeast and some mycelial fungi (Witthuhn et al., 2005). It is an irregular gelatin-like mass which may vary from 3 to $35 \mathrm{~mm}$ in diameter, having a cauliflower appearance and yellowish-white coloration. The flavor and aroma of kefir are the results of symbiotic metabolic activities and various species of bacteria and yeast are naturally found in kefir grains. Lactobacillus make up the bulk of the microbial population, as well as lactococcus and yeast (Otles \& Cagindi, 2003; Witthuhn et al., 2005). 
Given the above, the present research aimed to evaluate the incorporation of kefir in fish feed and the use of kefir for tilapia juveniles, aiming to produce juvenile fish with better zootechnical profiles, ensuring better performance due to a better structure of intestinal mucosa promoted by the action of the two types of kefir used (milk-based and water-based).

\section{Methodology}

The experiment was conducted at the Fish Industry Sector of the Department of Agrarian Sciences and the Laboratory of Biology and Physiology of Microorganisms at the University of José do Rosário Vellano. This research was positively evaluated by the Animal Experimentation Ethics Committee, under opinion n ${ }^{\circ} 12 \mathrm{~A} / 2018$.

The male fingerlings were obtained by donation from the New Fish Company $\left(21^{\circ} 21^{\prime} 32\right.$ "S and $\left.46^{\circ} 08^{\prime} 05^{\prime \prime} \mathrm{W}\right)$ and brought to the Psychology Sector of the José do Rosário Vellano-Unifenas-Alfenas-MG University (21 ${ }^{\circ} 27^{\prime 26}$ "S and $45^{\circ}$ $56 ' 35 \% \mathrm{~W}$ ) on February 22, 2018, undergoing a 7-day acclimatization period. The treatments started on 03/01/2018 and ended on $04 / 14 / 2018$.

For animal nutrition, commercial feed supplemented with two types of kefir was used, one grown in water and the other in milk. The commercial diet was submitted to bromatological analysis to verify the dry matter (DM), moisture (U), crude protein $(\mathrm{CP})$, ether extract $(\mathrm{EE})$, mineral matter $(\mathrm{MM})$ and crude fiber $(\mathrm{FB})$ contents, according to the described methodology by Silva and Queiroz (2002). The chemical and bromatological formulation of the commercial feed is presented in Table 1.

Table 1 - Chemical formulation and bromatological analysis (mean \pm standard deviation) of commercial diet for Tilapia juveniles.

\begin{tabular}{llll}
\hline Ingredients* & $\%$ & Composition Calculated (\%)** \\
\hline Rice bran & 11 & Dry matter & $94,06 \pm 0,37$ \\
Soy bean meal & 17 & Humidity & $5,93 \pm 0,37$ \\
Fish flour & 23 & Protein & $1,83 \pm 0,69$ \\
Soy protein & 39 & Eter extract & $6,01 \pm 0,93$ \\
Vitamins & 7 & Brute fiber & $1,83 \pm 0,69$ \\
Zinc oxide & 3 & Mineral material & $15,08 \pm 0,26$ \\
\hline
\end{tabular}

* Nutritional information from the manufacturer of commercial feed.

** Calculated composition - personal file.

Source: Authors.

\subsection{Feed preparation and microbiological analysis}

From the commercial feed, two groups of feed were prepared: the commercial feed group associated with kefir activated in milk and the commercial feed group associated with kefir activated in water. Each group generated two different types of ration. The first group consisted of ration supplemented with milk kefir grains and ration supplemented with fermented kefir milk. The second group, on the other hand, consisted of ration supplemented with kefir grains activated in water and ration supplemented with fermented kefir water. Thus, we obtained four different supplemented rations. These consisted of a dose of $4 \%$ of the different forms of kefir for each kg ration. The following types of rations were then prepared: 
Type 01: Milk ration and Kefir grain; Type 02: Feed and fermented milk from kefir; Type 03: Feed and Water Kefir Grain; Type 04: Feed and fermented water from Kefir.

The obtained diets were microbiologically analyzed to observe the incorporation of microorganisms present in the kefir to the diets. The different types of feed obtained by the combinations with kefir were diluted in the proportion of $25 \mathrm{~g}$ of feed to $225 \mathrm{~mL}$ of buffered protonated water, obtaining successive dilutions up to $10-3.1 \mathrm{~mL}$ aliquots of the dilutions were inoculated in duplicate onto plates containing Brain Heart Infusion agar (BHI) for the analysis of aerobic mesophiles, De Man, Rogosa and Sharpe agar for the evaluation of lactic acid bacteria and Sabouraud Glucose agar for yeast evaluation. Subsequently, the plates were incubated for 24-48 hours, showing the growth of colonies with different morphological characteristics. Macroscopic characteristics were evaluated and recorded, as well as morphology and staining characteristics by Gram stain (Silva et al., 2017).

From the colonies grown on the aforementioned agars, they were treated by using the MALDI Biotyper System method of protein extraction with formic acid for microbial identification using high yield MALDI-TOF mass spectrometry. Treatment was by transferring portions of cultured cells from a single colony to an Eppendorf tube containing $300 \mu \mathrm{L}$ of deionized water. Thus, a cell's suspension was generated, which was homogenized by successive pipetting and later shaking with a vortex mixer for about 30 seconds. Thereafter, $900 \mu \mathrm{L}$ of pure ethanol was added and the suspension was vortexed for 30 seconds and then the cell suspension was centrifuged for 2 minutes at 13,000 rpm and the supernatant was removed. The centrifugation was repeated to completely remove the ethanolic solution and the residue was collected using a pipette. Then 50 $\mu \mathrm{L} 70 \%$ formic acid was added to the Eppendorf, mixing, aggregating and pipetting and stirring. Subsequently, $50 \mu \mathrm{L}$ of acetonitrile was added and mixed into the suspension, adding and removing with a pipette. The microorganism extract was centrifuged for 2 minutes at $13,000 \mathrm{rpm}$. The supernatant was separated and stored in freezer microtubes $\left(-80^{\circ} \mathrm{C}\right)$ until analysis by the MALDI Biotyper System.

The MALDI Biotyper System, using MALDI-TOF mass spectrometry for interpretation of results, indicates the scores determined by the MALDI-TOF Microbial Identification System in a database. Thus the values indicated for the scores are:

- 2,300 to 3,000, highly probable species identification represented by the symbol (+++);

$-2,000$ to 2299 , secure identification of the genus, probable identification of the species, represented by the symbol $(++)$;

- 1700 to 1999, likely identification of the genus, represented by the symbol (+);

- 0.000 to 1699 , unreliable identification, represented by the symbol (-).

\subsection{Feed chemical analysis}

From each ration of the different treatments, $2 \mathrm{~g}$ were used to extract their components, using $10 \mathrm{~mL}$ of a mixed solution containing acetonitrile, water, methanol and isopropanol (1: 1: 1: 1). Subsequently, the solutions containing the samples were stirred at $95^{\circ} \mathrm{C}$ for $2 \mathrm{~h}$. After stirring, the samples were centrifuged for 10 minutes at $12,000 \mathrm{rpm}$. Two replicates of each sample were analyzed. The extracts were diluted 1:10 in water before 10 $\mu$ l analysis of each sample by UHPLC-MS (Mass Spectrometry Coupled Liquid Chromatography System).

Chromatographic separation was performed using a Nexera X2 (Shimadzu) system with a 10 x $2.1 \mathrm{~mm}$ BEH C18 1.7 column, $0.4 \mathrm{~mL} / \mathrm{min}$ solvent flow, with Solvent A: water + 0, $1 \% \mathrm{HCOOH}+0.025 . \% \mathrm{NH} 4 \mathrm{COOH}$ and Solvent B: methanol + $0.1 \% \mathrm{HCOOH}+0.025 \% \mathrm{NH} 4 \mathrm{COOH}$. The following $\mathrm{LC}$ gradient program was used: linear increase from $2 \% \mathrm{~B}$ to $98 \% \mathrm{~B}$ (over $17 \mathrm{~min}$ ), constant at 98\% B (over $1 \mathrm{~min}$ ). MS detection was performed using a Qq-TOF mass spectrometer (Compact 
model, Bruker Daltonik). The analyzes were acquired with ESI (Electron Spray Ionization) source in either positive or negative mode, scan mode combined with auto MSMS at a 3 Hertz acquisition rate.

Profile Analysis 2.1 software (Bruker Daltonik) was used for statistical analysis based on features extracted by the Find Molecular Features (FMF) algorithm that can combine all ions belonging to the same compound (isotopes, charge states, adducts and common neutral losses). Other data evaluations were performed using the Data Analysis 4.6 software (Bruker Daltonik) (Ates et al., 2013).

\subsection{Fish Treatment}

A completely randomized design was carried out in a $2 \times 2+$ control factorial scheme, in which two ways to activate kefir with milk or water were tested. Milk and grains and water and grains were used for the tests, with a dose of $4 \%$ of different forms for each $\mathrm{kg}$ of feed. These treatments had four repetitions. Each plot consisted of an aquarium with 10 tilapias. The treatments were: control, without kefir; Treatment 1: Kefir activated in milk, which was subdivided into Kefir activated grain with milk and fermented milk from Kefir and Treatment 2: Kefir activated with water and organic sugar, which was subdivided into Kefir activated with water and organic sugar and fermented water from kefir. For each of the 4 treatments, 4 aquariums were used.

The 200 fingerlings were distributed in 20 tanks with $250 \mathrm{~L}$ of circulation water. Water was evaluated for $\mathrm{pH}$, total dissolved ammonia, temperature and oxygen according to Kubitza (2000) and Mello et al. (2013). Siphoning of aquarium bottoms and water renewal decreased the accumulation of organic matter. The animals were fed 8 times a day as proposed by the company "Presence" to feed fingerlings of tilapia raised in a superintensive system.

\subsection{Zootechnical Evaluation}

All aquariums were monitored daily and measurements of total size (TT), partial size (TP), width (L) and weight (P) of the animal occurred every 15 days totaling 3 measurements over 45 days.

At the end of 45 days and after measurements, the animals from the same treatments were placed together in a transport bag and taken to the Microorganisms Biology and Physiology Laboratory. In the Laboratory, they were placed in boxes with water and benzocaine hydrochloride solution (1: $500 \mathrm{v} / \mathrm{v}$ ) for $10 \mathrm{~min}$ for deep anesthesia and euthanasia by brain section (According to Concea's Euthanasia Practice Guideline, 2015) on sanitized surface with 70\% GL From euthanasia, biological materials were collected for the analyzes. Fish from each treatment were divided into 2 groups of 20 animals, one group being referred for intestinal microbiological analysis and the other for intestinal morphometric analysis.

\subsection{Intestine Morphometric Analysis}

After euthanasia of the animals, fragments $(0.5 \mathrm{~cm})$ of the midgut were collected for morphological analysis of intestinal villi. After removal of the intestinal fragments, they were fixed in 10\% formalin for 24 hours, dehydrated in $70 \%$ alcohol, diaphonized and embedded in paraffin. Subsequently, microtomy was performed, as well as the cutting of the blade, followed by staining with hematoxylin and eosin (HE), according to Prophet et al. (1992), to evaluate the morphometric characteristics of the intestinal mucus.

The histological processing of the samples took place at the UNIFENAS Histopathological Laboratory. The parameters evaluated in the intestinal mucosa were total height and height, villus width and epithelium thickness, following the methodology of Ferreira et al. (2014). In each prepared slide, heights, widths, and thickness of the epithelium were measured in micrometers $(\mu \mathrm{m})$ of eight villi. 


\section{Results}

\section{Water quality parameters}

The physicochemical variables of water are represented (Table 2) and did not change between treatments throughout the experiment, being within the appropriate standards for the species (Kubitza, 2000).

Table 2 - Means and standard errors of water variables obtained from experiments with $O$. niloticus.

\begin{tabular}{|c|c|}
\hline Variable & Mean $\mathrm{OsO}$ \\
\hline Temperature & $26,3 \pm 1,3^{\circ} \mathrm{C}$ \\
\hline Oxygen & $4,8 \pm 0,8$ mg.L-1 \\
\hline$p H$ & $6,85 \pm 0,5$ \\
\hline Total ammonia & $0,25 \mathrm{mg} \cdot \mathrm{L}-1$ \\
\hline
\end{tabular}

Source: Personal Archive.

The physical-chemical quality of the water is essential for the fish to be able to express their zootechnical development. And for that expression, it must have a temperature with conditions of thermal comfort, oxygenation, $\mathrm{pH}$ and ammonia amount appropriate to the animal's performance and health.

\section{Microbiological Analysis of Feed}

The microbiological analyses showed the incorporation of microbial groups as lactic acid bacteria and yeast in the rations to which the kefir was added, as well as aerobic mesophiles. In commercial feed, without kefir, there was only the growth of aerobic mesophilic bacteria (Table 3).

Table 3 - Microbial identification and quantification (mean \pm standard deviation) in kefir samples and untreated or treated diets.

\begin{tabular}{|c|c|c|c|c|c|c|c|c|}
\hline \multicolumn{2}{|c|}{ Microrganisms } & \multirow{3}{*}{$\begin{array}{c}\text { Q Milk } \\
\begin{array}{c}1,2 \times 10^{5} \\
( \pm 3,5)\end{array}\end{array}$} & \multirow{3}{*}{$\begin{array}{c}\text { Q Water } \\
1,36 \times 10^{3} \\
( \pm 28,2)\end{array}$} & \multirow{3}{*}{$\begin{array}{c}\text { Control } \\
9 \times 10 \\
( \pm 5,6)\end{array}$} & \multirow{3}{*}{$\begin{array}{c}\text { T1A } \\
8,45 \times 10^{3} \\
( \pm 13,4)\end{array}$} & \multirow{3}{*}{$\begin{array}{c}\text { T1B } \\
6,05 \times 10 \\
( \pm 6,3)\end{array}$} & \multirow{3}{*}{$\begin{array}{c}\mathbf{T 2 A} \\
2,3 \times 10( \pm 4,2)\end{array}$} & \multirow{3}{*}{$\begin{array}{c}\text { T2B } \\
8,4 \times 10^{2}( \pm 2,8)\end{array}$} \\
\hline Aerobic & Mesofilic & & & & & & & \\
\hline Bacteria & & & & & & & & \\
\hline \multirow{2}{*}{\multicolumn{2}{|c|}{ Lactic Acid Bacteria }} & $1,2 \times 10^{5}$ & $1,1 \times 10^{5}( \pm 5,6)$ & & $1 \times 10^{5}( \pm 7,7)$ & $5,7 \times 10^{2}( \pm 2,8)$ & $5,6 \times 10^{3}( \pm 3,5)$ & $4,5 \times 10^{3}( \pm 5,6)$ \\
\hline & & $( \pm 9,1)$ & & & & & & \\
\hline Yeasts & & $1 \times 10^{5}( \pm 4,5)$ & $1 \times 10^{5}( \pm 4,5)$ & & $1 \times 10^{5}( \pm 4,5)$ & $1 \times 10^{5}( \pm 4,5)$ & $1 \times 10^{6}( \pm 4,9)$ & $1 \times 10^{6}( \pm 4,9)$ \\
\hline
\end{tabular}

T1A: Ration + Milk kefir grain; T1B: Ration + fermented milk

T2A: Ration + Grain of water kefir; T2B: Ration + fermented water Source: Personal Archive.

Besides the incorporation of microbial groups, it was possible to quantify them in the different diets, except in the commercial diet, which had no added kefir and, consequently, did not present count of lactic acid bacteria and yeasts, but only count of aerobic mesophilic bacteria. 
With the microbial growth in plaque and extraction of its proteins, it was possible to confirm the microbial groups as well as the identification of the microbiota diversity found in the kefir and the rations in which it was incorporated (Table 4).

Table 4 - Identification of the microbiota of the different types of feed treated or not treated with fermentation of lactose or sucrose, used in the nutrition of juveniles of $O$. niloticus for a period of 45 days of treatment from 01/03/18 to 14/04/04.

\begin{tabular}{|c|c|c|c|}
\hline Treatments/Kefir & Microrganisms & Score & Symbol \\
\hline \multirow{6}{*}{ Kefir milk } & Escherichia colli & 2370 & +++ \\
\hline & Escherichia colli & 2281 & ++ \\
\hline & Lactococcus lactis & 2028 & ++ \\
\hline & Enterococcus durans & 2041 & ++ \\
\hline & Kluyveromyces marxianus & 2362 & +++ \\
\hline & Kluyveromyces marxianus & 2265 & ++ \\
\hline \multirow{3}{*}{ Kefir water } & Lactococcus lactis & 2530 & +++ \\
\hline & Saccharomyces cerevisiae & 2150 & ++ \\
\hline & Kluyveromyces marxianus & 2352 & +++ \\
\hline \multirow{6}{*}{ Kefir grain milk } & Escherichia colli & 2370 & +++ \\
\hline & Escherichia colli & 2281 & ++ \\
\hline & Enterococcus durans & 2041 & ++ \\
\hline & Lactococcus lactis & 2028 & ++ \\
\hline & Kluyveromyces marxianus & 2362 & +++ \\
\hline & Kluyveromyces marxianus & 2265 & ++ \\
\hline \multirow{4}{*}{ Fermented milk } & Escherichia colli & 2454 & +++ \\
\hline & Escherichia colli & 2262 & ++ \\
\hline & Kluyveromyces marxianus & 2316 & +++ \\
\hline & Kluyveromyces marxianus & 2187 & ++ \\
\hline \multirow{3}{*}{ Kefir grain water } & Lactococcus lactis & 2149 & ++ \\
\hline & Kluyveromyces marxianus & 2265 & ++ \\
\hline & Saccharomyces cerevisiae & 2150 & ++ \\
\hline \multirow{5}{*}{ Fermented water } & Escherichia colli & 2232 & ++ \\
\hline & Escherichia colli & 2470 & +++ \\
\hline & Saccharomyces cerevisiae & 2150 & ++ \\
\hline & Kluyveromyces marxianus & 2352 & +++ \\
\hline & Kluyveromyces marxianus & 2265 & ++ \\
\hline \multirow{4}{*}{ Control } & Escherichia colli & 2372 & +++ \\
\hline & Escherichia colli & 2380 & +++ \\
\hline & Lysinibacillus fusiformis & 2226 & ++ \\
\hline & Leclercia adecarboxylata & 2243 & ++ \\
\hline
\end{tabular}

Source: Personal Archive.

Table 4 shows the microbial diversity found in the groups of lactic acid bacteria, aerobic mesophilic bacteria and yeasts. 


\section{Feed chemical analysis}

From the extraction of general metabolites from different treated and untreated samples, a profile of compounds analyzed by mass chromatography coupled with mass spectrometry was obtained. In this profile, the differences between these compounds were statistically evaluated. The results of the evaluation showed that the profile between the ration exposed to different conditions did not result in differences to the point of statistical separation between the groups. These results can be seen by the similarity of the base peak chromatograms (BPC) (Figures 1 and 2) as well as in the "score" graphs generated by the main component analysis (PCA) and by the hierarchical cluster analysis where it is not possible to visualize the separation of the samples (Figures 3).

By the base peak overlap in the chromatograms of the samples analyzed, the non-formation of groups in the score graphs and the hierarchical cluster analysis, it is explained that the samples are similar and showing the occurrence in both positive and negative mode.

Having the base peaks coinciding at the same points and the same areas, this means that all rations were isonutritive, not differing in their constitution despite being added that kefir ferments lactose and sucrose.

Figure 1 - Chromatogram of base peak analysis of feed constituents.
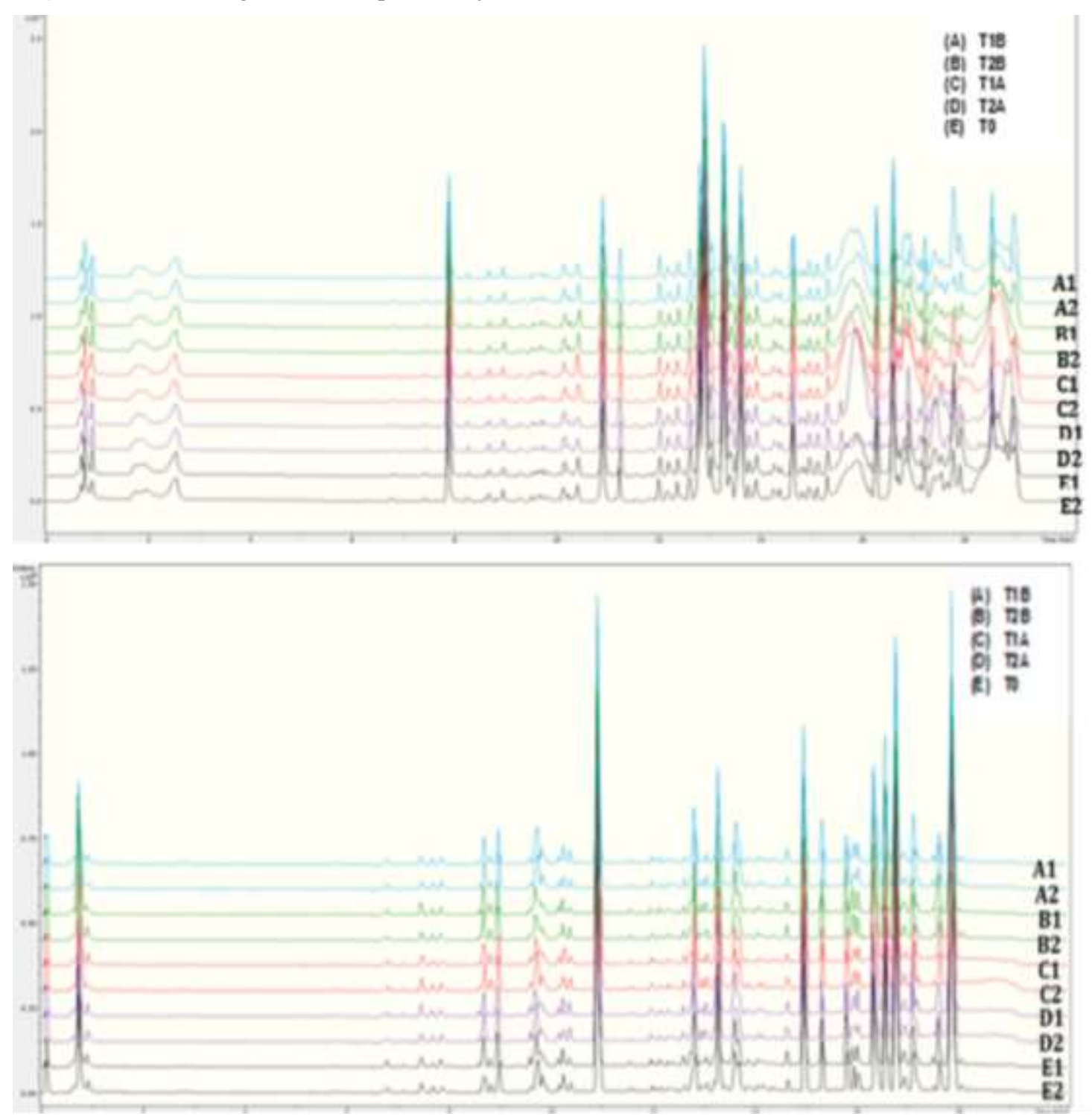

Source: Personal Archive. 
Research, Society and Development, v. 10, n. 2, e10610212209, 2021

(CC BY 4.0) | ISSN 2525-3409 | DOI: http://dx.doi.org/10.33448/rsd-v10i2.12209

Figure 2 - Principal Component Analysis (PCA) score graphs of samples of the various feed types in positive and negative mode.
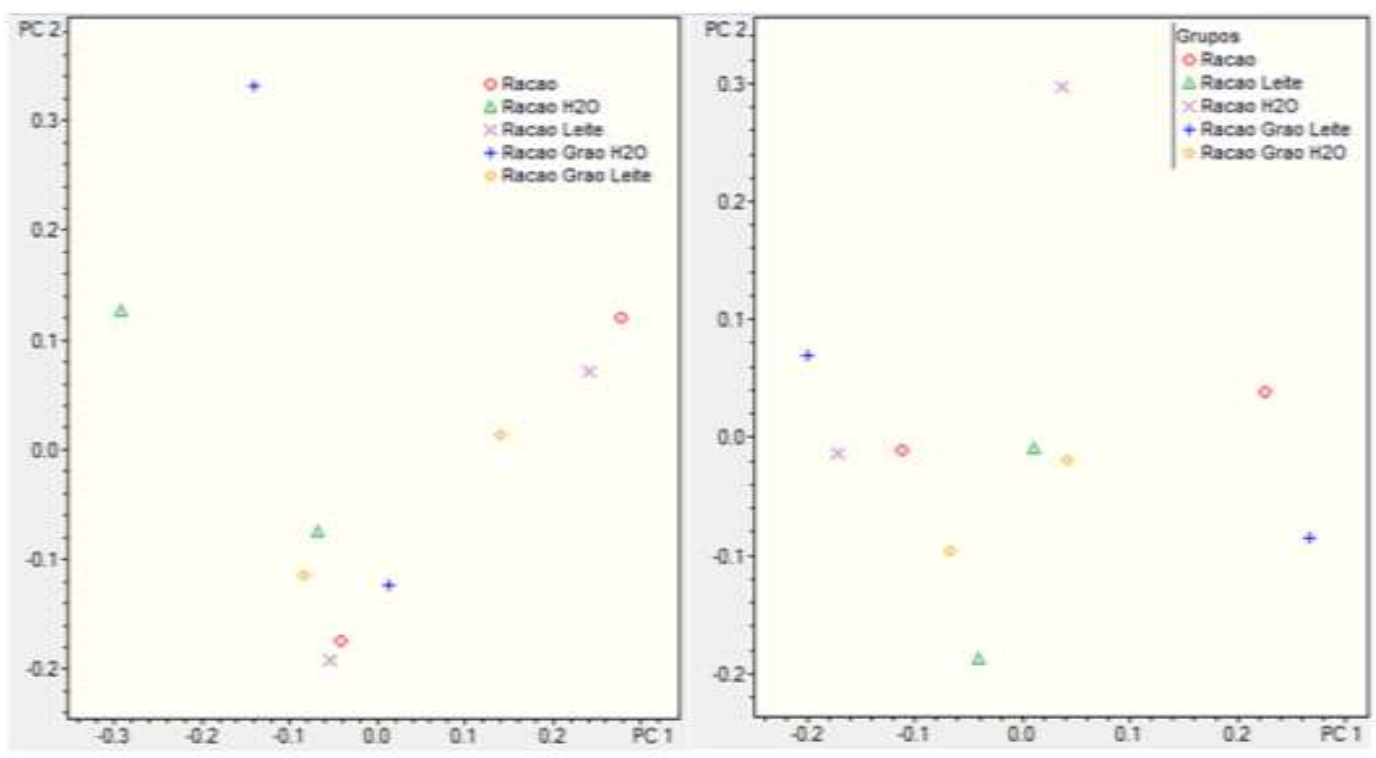

Source: Personal Archive.

Figure 3 - Statistical analysis of Hierachical Cluster (positive and negative mode).

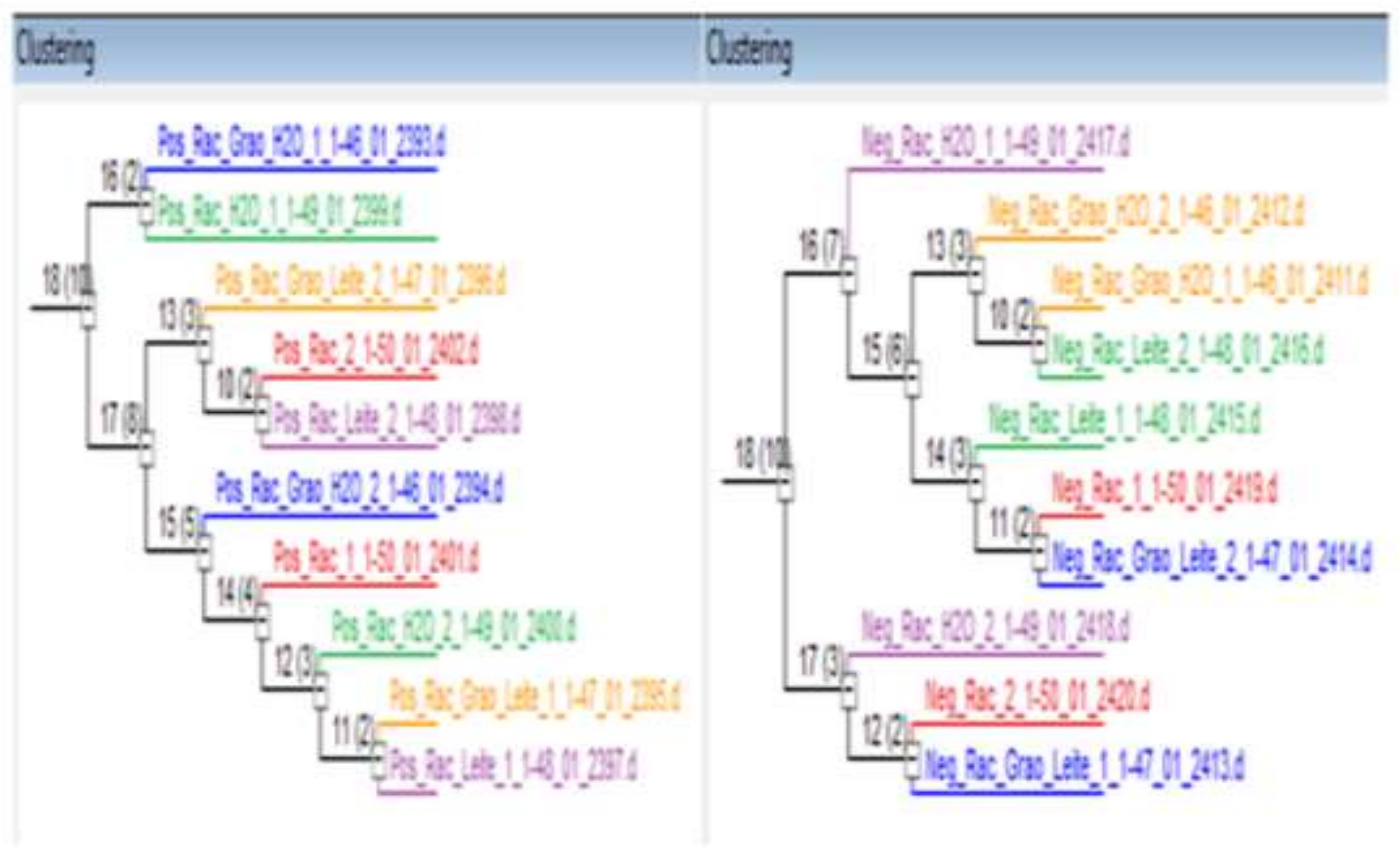

Note: Figures 4,5 were removed so as not to be repetitive since they were part of Figures 1,2 and 3. Source: Personal Archive.

The statistical analysis by hierarchical grouping did not demonstrate statistically separation between the groups of studied compounds, which corroborates with the results obtained in the base peaks of the chromatrograms and in the "score" graphs. 


\section{Zootechnical Evaluation}

He measures of total size (TT), partial size (TP), width (L) and weight (P) of the animal were statistically analyzed according to the $\mathrm{F}$ test $(\mathrm{P}<0.05)$. Among the evaluated parameters, there was only statistically significant difference concerning the total size in the total average of milk grain and water grain treatments when compared as control at 15 days and also between the total average of milk grain and water grain treatments. when compared to fermented milk and fermented water. It can also be observed the difference between the treatments in Table 5.

Table 5 - Growth average $(\mathrm{mm})$ in relation to the total size of O. niloticus over a 45-day period of treatment with or without the addition of chefir fermenting lactose or fructose between 03/01/18 to 04/14/18.

\begin{tabular}{llllll}
\hline $\begin{array}{l}\text { Measuring time } \\
\text { in days }\end{array}$ & Kefir & \multicolumn{2}{l}{ Control } \\
\cline { 3 - 5 } & & $\begin{array}{l}\text { Treatments } \\
\text { Activated } \\
\text { milk }\end{array}$ & $\begin{array}{l}\text { in } \\
\text { Activated in } \\
\text { water }\end{array}$ & Total & \\
\hline 15 & 18,50 & 17,00 & $17,75 \mathrm{~A}$ & \\
& Grain & 16,06 & 14,63 & $15,34 \mathrm{~B}$ & 16,31 \\
& Fermented & 17,28 & 15,81 & 16,55 & \\
\hline 30 & Total & 7,13 & 6,63 & 6,88 & \\
& Grain & 7,13 & 8,13 & 7,63 & 6,94 \\
& Fermented & 7,13 & 7,83 & 7,25 & \\
\hline 45 & Total & 25,63 & 23,63 & 24,63 & \\
& Grain & 23,19 & 22,75 & 22,97 & 23,25 \\
& Fermented & 24,41 & 23,19 & 23,80 & \\
\hline
\end{tabular}

Means followed by different letters differ by the $\mathrm{F}$ test $(\mathrm{P}<0.05)$.

Source: Personal Archive.

The other parameters (TT, TP, L, and P) did not present statistically significant differences when compared to the means of the treatments with the control nor between the treatments among themselves (Tables 6, 7 and 8) 
Research, Society and Development, v. 10, n. 2, e10610212209, 2021

(CC BY 4.0) | ISSN 2525-3409 | DOI: http://dx.doi.org/10.33448/rsd-v10i2.12209

Table 6 - Growth average $(\mathrm{mm})$ in relation to the partial size of O. niloticus over a 45-day period of treatment with or without the addition of kefir fermenting lactose or fructose between 03/01/18 to 04/14/18.

\begin{tabular}{|c|c|c|c|c|c|}
\hline \multirow{2}{*}{$\begin{array}{l}\text { Measuring time in } \\
\text { days }\end{array}$} & \multirow[t]{2}{*}{ Kefir } & \multicolumn{3}{|l|}{ Treatments } & \multirow[t]{2}{*}{ Control } \\
\hline & & Activated in milk & $\begin{array}{l}\text { Activated in } \\
\text { water }\end{array}$ & Total & \\
\hline \multirow[t]{3}{*}{15} & Grain & 9,75 & 9,50 & 9,63 & \\
\hline & Fermented & 9,31 & 8,13 & 8,72 & 9,25 \\
\hline & Total & 9,53 & 8,81 & 9,18 & \\
\hline \multirow[t]{3}{*}{30} & Grain & 3,25 & 3,25 & 3,25 & \\
\hline & Fermented & 3,50 & 3,38 & 3,44 & 3,31 \\
\hline & Total & 3,38 & 3,31 & 3,34 & \\
\hline \multirow[t]{3}{*}{45} & Grain & 13,00 & 12,75 & 12,88 & \\
\hline & Fermented & 12,81 & 11,50 & 12,16 & 12,56 \\
\hline & Total & 12,91 & 12,13 & 12,52 & \\
\hline
\end{tabular}

Means followed by different letters differ by the $\mathrm{F}$ test $(\mathrm{P}<0.05)$.

Source: Personal Archive

Table 7 - Growth average (mm) to width over 45 days of treatment from 01/01/18 to 04/14/18.

\begin{tabular}{|c|c|c|c|c|c|}
\hline \multirow{2}{*}{$\begin{array}{l}\text { Measuring time } \\
\text { in days }\end{array}$} & \multirow[b]{2}{*}{ Kefir } & \multicolumn{3}{|c|}{ Treatments } & \multirow[b]{2}{*}{ Control } \\
\hline & & $\begin{array}{l}\text { Activated in } \\
\text { milk }\end{array}$ & $\begin{array}{l}\text { Activated } \\
\text { in water }\end{array}$ & Total & \\
\hline \multirow{3}{*}{15} & Grain & 3,88 & 4,38 & 4,13 & \multirow{3}{*}{4,31} \\
\hline & Fermented & 3,75 & 3,38 & 3,56 & \\
\hline & Total & 3,81 & 3,88 & 3,84 & \\
\hline \multirow{3}{*}{30} & Grain & 2,00 & 2,38 & 2,19 & \multirow{3}{*}{1,75} \\
\hline & Fermented & 2,13 & 2,13 & 2,13 & \\
\hline & Total & 2,06 & 2,25 & 2,16 & \\
\hline \multirow{3}{*}{45} & Grain & 5,88 & 6,75 & 6,31 & \multirow{3}{*}{6,06} \\
\hline & Fermented & 5,88 & 5,50 & 5,69 & \\
\hline & Total & 5,88 & 6,13 & 6,00 & \\
\hline
\end{tabular}

Means followed by different letters differ by the $\mathrm{F}$ test $(\mathrm{P}<0.05)$.

Source: Personal Archive 
Table 8 - Growth average (g) in relation to weight gain of O. niloticus over a 45-day period of treatment with feed added or not by quefir fermenting lactose or fructose between 03/01/18 to 04/14/18.

\begin{tabular}{|c|c|c|c|c|c|}
\hline \multirow{2}{*}{$\begin{array}{l}\text { Measuring } \\
\text { time in days }\end{array}$} & \multirow[b]{2}{*}{ Kefir } & \multicolumn{3}{|c|}{ Tratamentos } & \multirow[b]{2}{*}{ Control } \\
\hline & & $\begin{array}{c}\text { Activated } \\
\text { in milk }\end{array}$ & $\begin{array}{l}\text { Activated } \\
\text { in water }\end{array}$ & Total & \\
\hline \multirow{3}{*}{15} & Grain & 1,95 & 1,75 & 1,85 & \multirow{3}{*}{1,72} \\
\hline & Fermented & 1,71 & 1,46 & 1,59 & \\
\hline & Total & 1,83 & 1,60 & 1,79 & \\
\hline \multirow[b]{3}{*}{30} & Grain & 0,74 & 0,70 & 0,72 & \multirow{3}{*}{0,88} \\
\hline & Fermented & 0,80 & 0,87 & 0,83 & \\
\hline & Total & 0,77 & 0,78 & 0,78 & \\
\hline \multirow{4}{*}{45} & Grain & 2,70 & 2,45 & 2,57 & \multirow{4}{*}{2,66} \\
\hline & Fermented & 2,51 & 2,33 & 2,42 & \\
\hline & & & & & \\
\hline & Total & 2,60 & 2,39 & 2,49 & \\
\hline
\end{tabular}

Means followed by different letters differ by the $\mathrm{F}$ test $(\mathrm{P}<0.05)$.

Source: Personal Archive

As a result of the present study, there was no statistically significant difference in zootechnical parameters, which corroborates the results of several studies that also used probiotics in fish food supplementation (Nakandakare, 2010; Albuquerque 2011; Tachibana et al., 2011; Farias 2012; Ferreira et al., 2015).

\section{Morphometric Evaluation}

Histomorphometric analysis of the intestine (Table 9) showed that the total height and height of the intestinal mucosa villi of $\mathrm{O}$. niloticus showed significantly lower total averages $(\mathrm{P}<0.05)$ in fish fed diet supplemented with kefir types $(\mathrm{T}$ kefir activated in milk, $\mathrm{T}$ fermented milk, $\mathrm{T}$ kefir grain in water and $\mathrm{T}$ fermented water), when compared with those of the control test animals. However, the villus width in the T-activated kefir grain treatment in milk was significantly higher $(\mathrm{P}<0.05)$ compared to the T-fermented milk and T kefir grain in water treatments. And the thickness of the epithelium showed no statistically significant difference between the various treatments. 
Table 9 - Average heights, width and thickness $(\mu \mathrm{m})$ of the intestinal mucosa villous epithelium of O. niloticus over a 45-day period of treatment with or without added ration to ferment lactose or fructose between 03/01/18 to 14 / 04/18.

\begin{tabular}{|c|c|c|c|c|c|c|}
\hline \multirow[b]{2}{*}{$\begin{array}{l}\text { Parameters } \\
\text { evaluated }\end{array}$} & \multirow[b]{2}{*}{ Kefir } & \multicolumn{3}{|c|}{ Treatment } & \multirow[b]{2}{*}{ Control } & \multirow[b]{2}{*}{$\mathrm{CV} \%$} \\
\hline & & $\begin{array}{l}\text { Activated in } \\
\text { milk }\end{array}$ & $\begin{array}{l}\text { Activated } \\
\text { in water }\end{array}$ & Total & & \\
\hline \multirow{3}{*}{ Villus Height } & Grain & 294,3 & 322,6 & 308,4 & \multirow{3}{*}{$361,4^{\mathrm{a}}$} & \multirow{3}{*}{0,46} \\
\hline & Fermented & 285,5 & 286,6 & 286,0 & & \\
\hline & Total & 289,8 & 304,6 & $297,2 b$ & & \\
\hline \multirow{3}{*}{$\begin{array}{l}\text { Alt. Total } \\
\text { villus }\end{array}$} & Grain & 332,5 & 365,4 & 348,9 & \multirow{3}{*}{$404,2^{\mathrm{a}}$} & \multirow{3}{*}{0,50} \\
\hline & Fermented & 328,8 & 318,5 & 330,6 & & \\
\hline & Total & 330,6 & 341,9 & $336,3 b$ & & \\
\hline \multirow{3}{*}{ Villus width } & Grain & $128,2 \mathrm{aA}$ & $104,0 \mathrm{~b}$ & $116,1 \mathrm{~A}$ & \multirow{3}{*}{108,7} & \multirow{3}{*}{2,25} \\
\hline & Fermented & $98,3 \mathrm{~B}$ & 104,6 & $101,4 \mathrm{~B}$ & & \\
\hline & Total & 113,2 & 104,3 & 108,7 & & \\
\hline \multirow{3}{*}{$\begin{array}{l}\text { Epithelium } \\
\text { Thickness }\end{array}$} & Grain & 53,3 & 48,8 & 51,0 & \multirow{3}{*}{51,5} & \multirow{3}{*}{3,47} \\
\hline & Fermented & 47,3 & 48,5 & 47,9 & & \\
\hline & Total & 50,3 & 48,6 & 49,4 & & \\
\hline
\end{tabular}

Means followed by different letters differ by the $\mathrm{F}$ test $(\mathrm{P}<0.05)$.

Source: Personal Archive

As can be seen in the statistical results of the histomorphometric analysis, none of the treatments influenced the structure of the intestinal epithelium.

\section{Discussion}

\section{Water quality parameters}

The physicochemical parameters of water are directly related to its quality, being indispensable for the productive potential to be expressed by fish (Kubtizia, 2000; Brito et al., 2019). The temperature for thermal comfort should be between 27 and $32{ }^{\circ} \mathrm{C}$ and when above these values can influence the appetite and growth. Since in the present study, it remained between $26.3 \pm 1.3^{\circ} \mathrm{C}$, and did not differ between the tanks during the experiment, but was considered low, according to Silva (2009) and Mello et al. (2013), for the survival of the species, but not interfering in the results regarding mortality. Brito et al., 2019 also report that the suboptimal temperature may negatively interfere with the development of O. niloticus.

Oxygen levels between 60 and $70 \%$ of saturation (above $4.5 \mathrm{mg} / 1$ ) are necessary for the proper performance and health of tropical fish Kubtiza, (2017) in agreement with the indices found in the present research.

A pH below 4.5 and above 10.5 can lead to significant mortality (Kubtizia, 2000). The values of pH $6.85 \pm 0.5$ and ammonia $0.25 \mathrm{mg} . \mathrm{L}-1$ were in agreement with the comfort range for the species and lower than the values found by Brito et al., 2019. 
Since water quality parameters outside this comfort zone can lead to changes in animal metabolism, generating excessive energy expenditures to maintain the organism's functioning that will induce a reduction in food consumption, compromising the fish performance (Brito et al., 2019).

Waste and waste eliminated by fish that accumulate at the bottom of the tank may interfere with variations in the chemical aspects of water during the experiment, so aquarium bottom siphoning and water renewal were necessary to prevent the accumulation of organic matter as determined by Brito et al. (2019).

\section{Microbiological Analysis of Feed}

In Brazil, the main difficulty in tilapia production is proper nutrition, coupled with correct food management, as food costs reach $65 \%$ of the total cost of production (Firetti \& Sales, 2004). The use of rations with kefir may be an alternative to improve the zootechnical profile, obtaining animals with greater resistance and weight gain, leading to a faster development, which may be advantageous in production costs.

Since kefir microorganisms promote better nutrient absorption, microbiological evaluation of the feed becomes important (Lemos et al., 2016).

According to Ribeiro (2015), the composition of kefir grains occurs by the presence of the following microorganisms: Lactobacillus homofermentative and heterofermentative, Lactococcus, Leuconostoc and Acetobacter.

Through microbiological analysis, we identified microbial groups of the kefirs used in this research. Table 4 shows the microbial profile of kefir fermented in milk and sugary water, the commercial feed used for the treatment formulations and the formulated feed with kefirs.

Regarding the microbiological profile of the milk-fermenting kefir, several studies have found a diversity of microorganisms characterized by the presence of lactic acid bacteria of the genus Lactobacillus paracasei, Lactobacillus parabuchneri, Lactobacillus casei, Lactobacillus kefiri), Lactococcus lactactus and yeasts Kluyveromyces lactis, Kazachstania aerobia, Saccharomyces cerevisiae and Lachancea meyersii (Magalhães, et al., 2011). Irrespective of the method of manufacture and type of culture, according to the Codex Allimentarius Standard (Codex Stan 243-2003), the typical kefir population should contain Lactobacilus Kefiri, Leuconostoc spp., Lactococcus spp. and Acetobacter spp. and lactosefermenting yeasts (Kluyveromyces marxianus), as well as lactose-free yeasts (Saccharomyces cerevisiae and Saccharomyces exigous) (Pogačić et al., 2013). Other authors indicate that, in kefir grains, a high microbiological diversity is found, including yeast species (Kluyveromyces, Pichia and Saccharomyces), lactic acid bacteria (Lactobacillus, Lactococcus, Leuconostoc and Streptococcus), acetic acid bacteria and other microorganisms not yet described (Garrote et al., 1997; 2001; Guven \& Gulmez, 2003; Miguel et al., 2010; Guzel-Seydim et al., 2011).

Thus, we can verify that the microbiological diversity that constitutes kefir is relatively large and varies among kefir samples, regardless of the substrate of kefir fermentation. From the studies of the authors cited above, it is clear that the agreement of the presence of specific groups of microorganisms, such as lactic acid bacteria and yeast. These results corroborate the microbiota found in the present study, although the types of microbial groups were smaller and also the diversity of microorganisms found in the specific groups of this study, which may have occurred due to the different methodologies employed, experimental conditions and samples used.

Also in another study, the following yeasts were found: Candida kunwiensis, Kluyveromyces lactis, Debaryomyces occidentalis, Anomalous Dekkera, Kluyveromyces marxianus, Torulaspora delbrueckii, Debaryomyces occidentalis and Pichia sydowiorum (Magalhães, 2008). In the present study, we found a lower diversity of yeasts (Saccharomyces cerevisiae and Kluyveromyces marxianus), but they were also found in Magalhães et al. (2008) and Magalhães et al. (2010) research. 
In the microbial profile of the formulated diets for feeding of O. niloticus juveniles, the same microorganisms found in the milk and water kefir are present. The presence of E. coli in the milk kefir and its formulations is due to possible contamination of the milk used for fermentation and contamination of the feed itself. The feed treated with water suspension and organic sugar that presented in its profile the presence of E.coli may be justified because the commercial diet has this bacterium. The feed treated with the kefir grain from water and organic sugar did not present this bacterium possibly due to bacteriocins produced by the microorganisms present in the kefir grain used. The production of bacteriocins by the different types of kefir has been described by some authors (Coppola \& Turnes 2004; Ribeiro, Costa \& Logato, 2008) which corroborates the results of the present study.

\section{Feed chemical analysis}

The results obtained by mass spectrometry, through the extraction of feed metabolites, show that the profile of the different feed compositions does not result in significant differences to the point of statistical separation between the groups in the present study. If differences are found, differential compounds can be characterized and evaluated for chemical or biological relevance in the study of feed.

The positive effects of growth promoters on productive performance in animals are not always evidenced. This may be related to the characteristics of each probiotic used in various species, the type of dietary ingredient or the stress level to which animals are subjected (Brito et al., 2019).

\section{Zootechnical Evaluation}

According to statistical analysis by the $\mathrm{F}$ test $(\mathrm{P}<0.05)$ it was possible to detect significant statistical differences only in the total average concerning the total size of the animals of the treatments T-kefir activated in milk and T-kefir activated in water with sugar, when compared as a control at 15 days and also between the total treatments T-activated kefir grains in milk and $\mathrm{T}$-activated kefir grain in sugary water when compared to $\mathrm{T}$ fermented milk and $\mathrm{T}$ fermented water.

After 15 days neither treatments expressed significant differences regarding the zootechnical parameters analyzed (TT, TP, L, and P) and there was no animal mortality in the experimental period. Thus, as there were no nutritional differences between the diets exposed to the various treatments with which to use tilapia feed, they are isonutritive, corroborating the results of other research (Nakandakare, 2010; Tachibana et al., 2011; Farias 2012 ).

A similar study by Farias (2012), also obtained the same results with the inclusion of probiotic B. subtilis and B. cereus in pacu diets. After Nakandakare (2010) offered diets with different inclusion methods, there were also no significant differences regarding weight gain and survival.

The studies by Tachibana et al. (2011), which evaluated the zootechnical performance of Nile tilapia during the sexual inversion phase, using the Bacillus subtilis probiotic, did not observe differences ( $p>0.05$ ) concerning the gain parameters. weight, total length, specific growth rate, final biomass, and survival. Ferreira et al., 2015, working with the Saccharomyces cerevisiae probiotic strain in Nile tilapia post-larvae within 30 days of sanitary challenge (sheep feces), did not observe a significant effect on performance parameters.

Albuquerque (2011) also observed that there was no improvement in weight gain, evaluating the potential of two probiotics (Bacillus cereus, Bacilos subtilis) concerning a control treatment. With the formulations that did not contain any bacteria offered to fish, they presented higher final weight $(\mathrm{P}>0.05)$ than with $\mathrm{B}$. subtilis addition. However, comparing with the fish that received the bacterium B. cereus, it was observed that there was no difference between them.

Supplementation with yeast and derivatives improves the productive performance of tilapia, as shown in their studies Hisano et al. (2008). They found in this study that autolyzed yeast, when used between 1.30 and $1.59 \%$, provides higher performance. 
In the experiment by Aly, Mohamed and John (2008), different results were described, with the addition of B. subtilis in the Nile tilapia fingerling diet, obtaining greater weight gains about the control treatment.

The different responses of zootechnical performance can be attributed to the different experimental conditions, as environmental factors (dissolved oxygen, temperature, $\mathrm{pH}$ ), for aquatic organisms that are more dependent on the establishment and proliferation of probiotic bacteria in the host intestinal tract (Das \& Ward Burke, 2008; Mehrirn, 2009).

\section{Bowel morphometric assessment}

Measurement of villus height and density are parameters for assessing the integrity of the intestinal mucosa. Cell loss and renewal usually occur in a balanced manner in the intestine, maintaining constant epithelial renovation, villus size, and consequently digestive and intestinal absorption capacity (Ferreira et al., 2014). In contrast, when altering the intestinal microbiota by foreign microbial agents to the gut, an imbalance and intervention in this cell renewal may occur, modifying the height, length, and thickness of the villi (Pelicano et al., 2003).

In the present study, only the partial and total villus height did not show a statistically significant increase by the $\mathrm{F}$ test ( $\mathrm{P}<0.05$ ), in relation to the control ration and the rations treated with the types of kefir (Figure 4). The widths of villi analyzed in the intestinal mucosa were superior to those of the control group in the activated grain treatment in milk and the total treatments average at the end of 45 days. Also, the villus width in the fermented milk treatment was significantly lower, according to the $\mathrm{F}$ test $(\mathrm{P}<0.05)$ when compared to activated grain treatment in the milk (Figure 5). The thickness of the epithelium was not affected by the treatments since there was no statistical difference between the treatments and neither between the controls.

In contrast, Mello et al., 2013 found in their research that fish fed diets containing the probiotic showed significant differences in the structural constitution of the mucosal villus epithelium when compared to those observed in the control fish.

This difference between the responses obtained in these studies may be a function of treatment time, and a longer probiotic use could favor bacterial colonization and, consequently, favor intestinal morphology and absorption.

Regarding time, Carnevali et al. (2004) observed that, during the first 35 days of breeding of sea bream larvae (Brama australis), the anaerobic and intestinal aerobic bacteria had not changed with the inclusion of Lactobacillus spp. After the 66th day of supplementation, significant changes in the intestinal microbiota were observed.

The microorganisms contained in probiotics, able to colonize the intestine, must adapt to the physical, chemical and biotic specificity of the intestinal environment and resist the actions of bile, digestive enzymes, host immune system, anaerobiosis and $\mathrm{pH}$ variations. Successful colonization also involves competition with other bacteria for binding sites, nutrients, and toxin resistance produced by other bacteria (Makridis et al., 2000; Ouwehand et al., 2002; Vaughan et al., 2002).

Alterations in intestinal mucosal morphology may also occur when a microbial agent comes into contact with the intestine, leading to imbalance and interference with cell renewal, changing villus height, length, and thickness (Pelicano et al., 2003). Studies using probiotics based on Bacillus cereus and Bacillus subtilis or mannan oligosaccharide (MOS) prebiotics for Nile tilapia larvae, fingerlings and juveniles (Oreochromis niloticus) demonstrated that probiotics and prebiotics promoted higher intestinal villus height and thicker mucosal epithelium (Carvalho et al., 2011; Schwarz et al., 2011; Cechim 2012; Mello et al., 2013).

In other species, such as bijupirá larvae (Rachycentron canadum) (Salze et al. 2008) and juvenile rainbow trout (Oncorhynchus mykiss) (Yilmaz et al., 2007), greater height was found in intestinal villi after MOS supplementation in the diet.

However, although the literature reports beneficial effects of the use of these additives on the intestinal mucosa in some fish species (Hisano et al., 2008; Carvalho et al., 2011; Schwarz et al., 2011; Mello et al., 2013), by morphological 
analysis. In the present study, it can be considered that there were no significant changes in the morphological characteristics of the intestinal tract, indicating that, regardless of the way it was applied, the probiotic (kefir) used had no effect on the increase in the absorption area of the intestinal mucosa. of tilapia juveniles.

This study, which had a different probiotic administration of $4 \%$ for each $\mathrm{kg}$ of feed for up to 45 days of treatment, presented similar results to the study on the histomorphometric characterization of the intestine of surubins (Pseudoplatystoma ssp.) fed for 20 days with diet. supplemented with probiotic (Bacillus subtilis) at feed doses of 10, 20, 30 and 40g / $\mathrm{kg}$, which presented negative effects about the height of the intestinal villi, suggesting that there was no benefit of the additive on intestinal histomorphometry (Nunes, 2013). Another study, which evaluated histomorphometric characteristics of the intestinal mucosa of tambaqui after the use of Bacillus spp. carried in the feed $(1.0 \mathrm{~g} / \mathrm{kg}$ feed) and dissolved in water (20 $\mathrm{mg} / \mathrm{L})$ during transport, the probiotic also presented negative effects about the height and length of tambaqui intestine villi challenged with transport (Ferreira et al., 2014).

Looking at the results of the present study, compared to the results of Nunes, 2013 and Ferreira et al., (2014), it can be noted that there is a relationship between dose and time of administration of the probiotic that should be well established, besides being necessary a basic knowledge of the digestive physiology of fish so that diets that meet the nutritional requirements of farmed species can be developed. However, there is little information available in the literature involving the morphophysiology of the fish digestive system.

Figure 4 - Villus thickness in treatments.
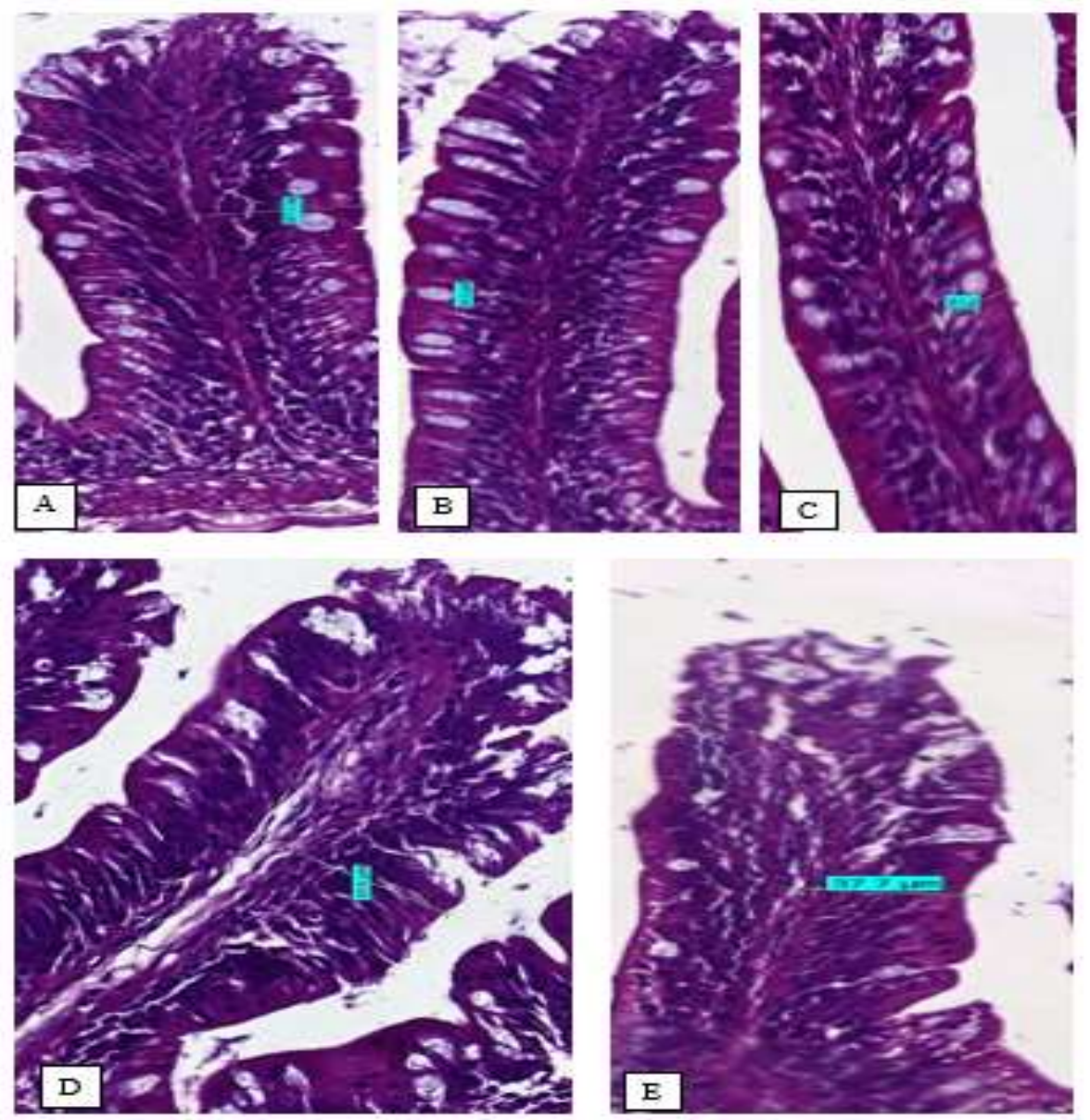

A - T kefir grain activated in milk; B - T fermented milk; C - Grain of kefir activated in sugar water; D - T fermented water; E- Control. Source: Personal Archive 
It is evident in Figure 4 that there was no interference from treatments in the partial and total height of the intestinal villi.

Figure 5 - Villus width in treatments.
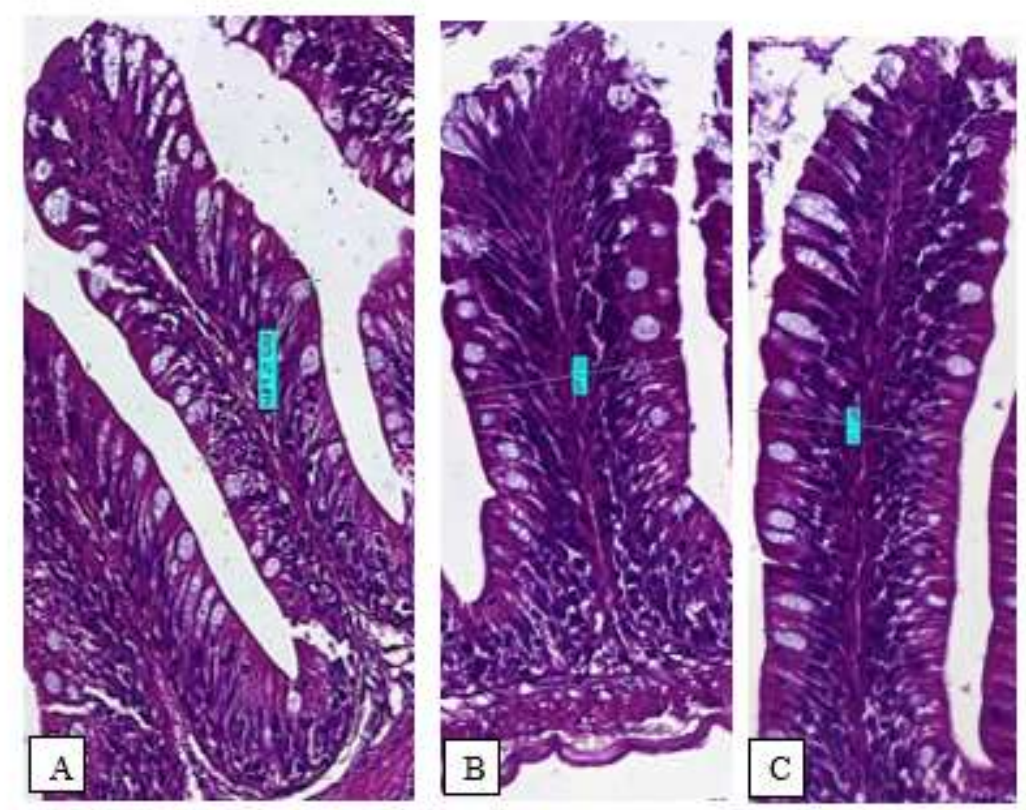

A - T activated kefir grain in milk; B - T fermented milk; C - Control Source: Personal Archive

In Figure 5, an increase in the width of intestinal villi was demonstrated in the activated grain treatment in milk when compared to the control group.

\section{Conclusion}

Given the analyzes performed in the feed, it can be concluded that there was the incorporation of the kefir microbiota in them due to its presence. According to the results, it can be inferred that the number of colony-forming units was not sufficient to interact with the intestinal microbiota and that there was no necessary treatment time for epithelial alteration to occur.

From the evaluations carried out in the intestinal mucosa of juveniles of Oreochromes niloticus, fed with rations supplemented with kefir grown in milk and brown sugar water, it was concluded that occasional alterations occurred in the intestinal mucosa were not sufficient for a better zootechnical profile. ensure better performance. It was also concluded that the experimental conditions did not interfere in the research since there was no mortality of the animals during the study period. Thus, further studies are needed on the digestive physiology of this fish species and also on the mechanism of colonization and action of probiotics in improving intestinal epithelium and nutrient absorption. Thus, still rest a proposal of new studies about food supplementation with concentrations above $4 \%$ of inclusion of kefir in the diets and with an increase in treatment time.

\section{References}

Abdel-Tawwab, M., Abdel-Rahman, A., \& Ismael, N. (2008). Evaluation of commercial live bakers' yeast, Saccharomyces cerevisiae as a growth and immunity promoter for Fry Nile tilapia, Oreochromis niloticus (L.) challenged in situ with Aeromonas hydrophila. Aquaculture, 280 (1-4), 185-189.

Aly, S., Mohamed, M. F., \& John, G. (2008). Effect of probiotics on the survival, growth and challenge infection in Tilapia nilotica (Oreochromis niloticus). Aquaculture research, 39 (6), 647-656. 
Albuquerque, D. M. (2011). Bacillus cereus var. Toyoi e Bacilos subtilis C-3102 em dietas para alevinos de tilápia do Nilo, linhagem GIFT. Dissertação de Mestrado em Engenharia de Pesca e Recursos Pesqueiros. Paraná: Universidade Estadual do Oeste do Paraná.

Associação Brasileira da Piscicultura - PeixeBR. (2019). Anuário Peixe BR da Piscicultura. https://www.peixebr.com.br/Anuario2019/A nuarioPeixeBR2019.pdf?

Ates, E., Mittendorf, K., Stroka, J., \& Senyuva, H. (2013). Determination of Fusarium mycotoxins in wheat, maize and animal feed using on-line clean-up with high resolution mass spectrometry. Food Additives \& Contaminants: Part A, 30(1), 156-165.

Baccarin. A. E., \& Pezzato, L. E. (2001). Efeito da levedura desidratada de álcool em dietas para tilápiado-Nilo. Pesquisa Agropecuaria Brasileira, 36(3), $549-556$.

Brito, J. M., Ferreira, A. H. C., Santana Júnior, H. A., Oliveira, A. P. A., Santos, C. H. L., \& Oliveira, L. T. S. (2019). Desempenho zootécnico de juvenis de tilápias do nilo (Oreochromis niloticus) alimentados com cepas probióticas e submetidos a desafio sanitário. Ciência Animal Brasileira, 20 , e-37348.

Carnevali O., Zamponi M. C., Sulpizio R., Rollo A., Nardi M., Orpianesi C., Silvi S., Caggiano M., Polzonetti A. M., \& Cresci A. (2004). Administration of probiotic strain to improve sea bream wellness during development. Aquacult. Int. 12, 377-386.

Carvalho, J. V., Lira, A. D., Costa, D. S. P., Moreira, E. L. T., Pinto, L. F. B., \& Albinati, R. C. B. (2011). Desempenho zootécnico e morfometria intestinal de alevinos de tilápia-do-Nilo alimentados com Bacillus subtilisou mananoligossacarídeo. Rev. Bras. Saúde Prod. Anim. 12, $176-187$.

Cyrino, J. E. P., Bicudo, A. J. A, Sado, R., \& Borghesi, R. (2010). Fish farming and the environment: the use of environmental friendly feeds in fish culture. Revista Brasileira de Zootecnia, 39, 68-87.

Cechim, F. E. (2012). Características morfológicas do epitélio intestinal e desempenho de Tilápia-do-Nilo, Oreochromis niloticus, suplementada com mananoligossacarídeo (MOS). Dissertação de Mestrado em Produção Animal, Paraná: Universidade Tecnológica Federal do Paraná.

Codex Alimentarius Commission. (2003). Codex Standart for fermented milks: Codex STAN 243: FAO/WHO, Food Standard, Rome.

Silveira, U. S., Logato, P. V. R., \& Pontes, E. D. C. (2009). Fatores estressantes de peixes. Revista Eletrônica Nutritime, 6 (4), $1001-1017$.

Das, S., Ward, L. R., \& Burke, C. (2008). Prospects of using marine actinobacteria as probiotics in aquaculture. Applied Microbiology and Biotechnology, 81 (3), 419-429.

Menezes Coppola, M., \& Turnes, C. G. Probióticos e resposta imune. Ciência Rural, 34(4), 1297-1303.

El-Rhman, A. M., Khattab, Y. A. E., \& Shalaby, A. M. E. (2009). Micrococcus luteus and Pseudomonas species as probiotics for promoting the growth performance and health of Nile tilapia, Oreochromis niloticus. Fish \& Shellfish Immunology, 27(2), 175-180.

Food And Agriculture Organization Of The United Nations - Fao. (2012). Anuários de Estadísticas de Pesca: Producción de acuicultura 2012. http://www.fao.org/fishery/statistics/global-aquaculture-production/en.

Farias, THV. (2012). Probiótico na alimentação do pacu (Piaractus mesopotamicus): avaliação hematológica, bioquímica, imunológica e desempenho produtivo. Dissertação de Mestrado em Aquicultura. Jaboticabal: Universidade Estadual Paulista "Júlio De Mesquita Filho".

Ferreira, C. M., Antoniassi, N. A. B., Silva, F. G., Povh, J. A., Potença, A., Moraes, T. C. H., Silva, T. K. S. T., \& Abreu, J. S. (2014). Características histomorfométricas do intestino de juvenis de tambaqui após uso de probiótico na dieta e durante transporte. Pesq. Vet. Bras., 34 (12), $1258-1264$.

Ferreira, A. H. C., Brito, J. M., Lopes, J. B., Santana Júnior, H. A., Batista, J. M. M., Silva, B. R., Souza, E. M., \& Amorim, I. L. S. (2015). Probiótico na alimentação de pós-larvas de tilápias do Nilo submetidas a desafio sanitário. Revista Brasileira de Saúde e Produção Animal. $2015 ; 16$ (2), $430-439$.

Firetti, R., \& Sales, D. S. (2004). O futuro promissor da cadeia produtiva da piscicultura comercial. Anualpec, 11, $305-307$.

Furuya, W. M., Pezzato, L. E., Barros, M. M., \& Cyrino, J. E. P. (2012). Exigências nutricionais e alimentação em tilápia. In: Fracalossi, D. M., \& Cyrino, J. E. P. Nutrição e alimentação de espécies de interesse para a aqüicultura brasileira. Nutriaqua. Florianópolis: Copiart.

Garrote, G. L., Abraham, A. G., \& Antoni, G. L. (1997). Preservation of kefir grains, a comparative study. LWT-food science and technology, 30 (1), 77-84.

Garrote, G. L., Abraham, A. G., \& Antoni, G. L. (2001). Chemical and microbiological characterisation of kefir grains. Journal of dairy research, 68 (4), 639652 .

Guzel-Seydim, Z. B., Kok-Tas, T., Greene, A. K., \& Seydim, A. C. Review: functional properties of kefir. Critical Reviews in Food Science and Nutrition, 51 (3), 248- 260 .

Güven, A., Güven, A., \& Gülmez, M. (2003). The Effect of Kefir on the Activities of GSH-Px, GST, CAT, GSH and LPO Levels in Carbon Tetrachloride-Induced Mice Tissues. Journal of Veterinary Medicine, Series B, 50 (8), 412-416.

Hisano, H., Sampaio, F. G., Barros, M. M., \& Pezzato, L. E. (2008). Composição nutricional e digestibilidade aparente da levedura íntegra, da levedura autolisada e da parede celular pela tilápia-do-Nilo. Ciência Animal Brasileira, 9 (1), 43-49.

Holzapfel, W., Schillinger, U., Du Toit, M., \& Dicks, L. (1998). Systematics lactic acid bacteria with reference to modern phenotypic and genomic methods. Microecology and Therapy, 10, 1-10.

Kubitza, F. (2000). Tilápia: tecnologia e planejamento na produção comercial. Editora Kubitza. 
Kubitza, F. (2017). A água na aquicultura - Parte I | Oxigênio dissolvido e sua importância para o desempenho e saúde dos peixes e camarões. Panorama na Aquicultura, 27 (162), 24-33.

Lara-Flores, M., Olvera-Novora, M. A., Guzmám-Méndez, B. E., \& López-Madrid, W. (2003). Use of the bacteria Streptococcus faecium and Lactobacillus acidophilus, and the yeast Saccharomyces cerevisiae as growth promoters in Nile tilapia (Oreochromis niloticus). Aquaculture, 216 (1-4), 193-201.

Lemos, M. J., Calixto, L. F. L., Torres-Cordido, K. A. A., \& Reis, T. L. (2016). Use of a balancing food additive of the intestinal flora for broilers and laying. Arquivos do Instituto Biológico, 83, e0862014.

Lee, Y., \& Salminen, S. (1995). The coming of age of probiotics. Trends in Food Science \& Technology, 6 (7), 241-245.

Magalhães, K. T. (2008). Caracterização microbiológica e química da bebida quefir de leite e açúcar mascavo. Dissertação de Mestrado em Microbiologia Agrícola. Lavras: Universidade Federal de Lavras.

Magalhães, K. T., Pereira, G. V. M., Campos, C. R., Dragone, G., \& Schwan, R. F. (2011). Brazilian kefir: structure, microbial communities and chemical composition. Brazilian Journal of Microbiology, 42, 693-702.

Magalhães, K. T., Pereira, G. V. M., Dias, D. R, \& Schwan, R. F. (2010). Microbial communities and chemical changes during fermentation of sugary Brazilian kefir. World J Microbiol Biotechnol 26 (7), 1241-1250.

Makridis P., Fjellheim A. J., Skjermo J. \& Vadstein O. (2000). Colonization of the gut in first feeding turbot by bacterial strains added to the water or biencapusated in rotifers. Aquacult. Int., 8 (5), 367-380.

Hurzana, J. R.E., Mello, H., Moraes, J. R. E., Niza, I. G., Moraes, F. R., Ozório, M. T. S., Filho, J. R. E., \& Claudiano, G. (2013). Efeitos benéficos de probióticos no intestino de juvenis de Tilápia-do-Nilo. Pesquisa Veterinária Brasileira, 33 (6), 724-730.

Meurer, F., Silva, M., Costa, M., \& Colpini, L. (2009). Probiótico com levedura na alimentação da tilápia do Nilo, durante o período de reversão sexual, cultivada em água de tanque de cultivo. Revista Brasileira de Saúde e Produção Animal, 10 (2), 1179.

Mehrirn, A. L. (2009). Effect of Dietary Supplementation of Biegen® (Commercial IYobiotic) on Mono-Sex Nile ti la pin Orcockromis niloticus under Different Stocking Densities. J. Fish. Aquat. Sci, 4 (6), 261-273.

Miguel, M. G. C. P., Cardoso, P. G., Lago, L. A., \& Schwan, R. F. Diversity of bacteria present in milk kefir grains using culture-dependent and cultureindependent methods. Food Research International, 43, 1523-1528.

Nayak, S. K. (2010). Role of gastrointestinal microbiota in fish. Aquaculture Research, 41 (1), 1553-1573.

Nakandakare, I. B. (2010). Inclusão de probióticos durante o processamento de ração para tilápias do Nilo, Oreochromis niloticus, variação Gift. Dissertação de Mestrado em Aqüicultura e Pesca. Instituto de Pesca.

Nunes A. L. (2013). Probiótico na dieta de surubins Pseudoplatystoma spp. Dissertação de Mestrado em Zootecnia. Aquidauana: Universidade Estadual de Mato Grosso do Sul.

Oenning, J. P. (2013). Cultivo de tilápia do nilo no período de inverno. Trabalho de Conclusão de Curso em Aquicultura. Palotina: Universidade Federal Do Paraná.

Otles, S., \& Cagindi, O. (2003). Kefir: a probiotic dairy-composition, nutritional and therapeutic aspects. Pakistan Journal of Nutrition, 2 (2), $54-59$.

Ouwehand A. C., Salminen S., \& Isolauri E. (2002). Probiotics: an overview of beneficial effects. Antonie van Leeuwenhoek, 82, 279-289.

Panigrahi, A., \& Azad, I. S. (2007). Microbial intervention for better fish health in aquaculture: the Indian scenario. Fish physiology and biochemistry, 33 (4), 429-440.

Pelicano E. R. L., Souza P. A., Souza H. B. A., Oba A., Norkus C. E. A., Kodawara L. M. \& Lima T. A. (2003). Morfometria e ultra-estrutura da mucosa intestinal de frangos de corte alimentados com dietas contendo diferentes probióticos. Revta Port. Ciênc. Vet. 98, 125-134.

Prophet, E. B., Mills, B., Arrington, J. B., \& Sobin, L. H. (1992). Laboratory Methods in Histotechnology. Washington: Armed Forces Institute of Pathology.

Pogačić, T., Zamberlin, S., Samarzija, D., \& Sinko, S. (2013). Microbiota of kefir grains. Mljekarstvo, 63 (1), 3-14.

Ribeiro, A. S. (2015). Caracterização de micro-organismos com potencial probiótico isolados a partir de kefir produzidos na região noroeste do estado do Rio Grande do Sul. Dissertação de Metrado em Ciência e Tecnologia dos Alimentos. Santa Maria: Universidade Federal de Santa Maria.

Ribeiro, P. A. P., Costa, L. S., \& Logato, P. V. R. (2008). Probióticos na aquicultura. Rev. Nutritime, 6 (1), 837-846.

Rodrigues, K. L, Caputo, L. R. G., Carvalho, J. C. T., Evangelista, J., \& Schneedorf, J. M. (2005). Antimicrobial and healing activity of kefir and kefiran extract. International journal of antimicrobial agents, 25 (5), 404-408.

Sahu, M. K., Swarnakumar, N. S., Sivakumar, K., Thangaradjou, T., \& Kannan L. (2008). Probiotics in aquaculture: importance and future perspectives. Indian journal of microbiology, 48 (3), 299-308.

Silva, D. J., \& Queiroz, A. C. (2002). Análise de alimentos: Métodos Químicos e Biológicos. (3a ed.), Universidade Federal de Viçosa.

Silva, D. J., \& Queiroz, A. C. (2009). Análise de alimentos: métodos químicos e biológicos. (3a ed.), Universidade Federal de Viçosa.

Silva, N., Junqueira, V. C. A., Silveira, N. F. A., Taniwaki, M. H., Gomes, R. A. R., \& Okazami, M. M. (2017). Manual de Métodos de Análise Microbiológica de Alimentos e água. São Paulo: Blucher. 
Research, Society and Development, v. 10, n. 2, e10610212209, 2021

(CC BY 4.0) | ISSN 2525-3409 | DOI: http://dx.doi.org/10.33448/rsd-v10i2.12209

Schwarz, K. K., Furuya, W. M., Natall, M. R. M., Gaudez, M. C., \& Lima, P. A. G. (2011). Mananoligossacarídeo em dietas para larvas de tilápia. R. Bras. Zootec. 40 (12), 2634-2640.

Tachibana, L., Dias, D. C., Ishikawa, C. M., Corrêa, C. F., Leonardo, A. F. G., \& Ranzani-Paiva, M. J. T. (2011). Probiótico na alimentação da tilápia do Nilo (Oreochromis niloticus Linnaeus, 1758), durante a inversão sexual: desempenho zootécnico e recuperação da bactéria probiótica intestinal. Bioiko, 25 (1), 25 31.

Vaughan, E. E., Vries, M. C., Zoetendal, E. G., Ben-Amor, K., Akkermans, A. D. L., \& Devos, W. M. (2002). The intestinal LABs. Antoinie von Leeuwenhoek, 82, 341-352.

Yilmaz E., Genc, M. A. \& Genc, E. (2007). Effects of dietary mannan oligosaccharides on growth, body composition, and intestine and liver histology of rainbow trout, Oncorhynchus mykiss. Isr. J. Aquac. Bamidgeh, 59, 182- 188.

Witthuhn, R. C., Schoeman, T., \& Britz, T. J. (2005). Characterisation of the microbial population at different stages of Kefir production and Kefir grain mass cultivation. International Dairy Journal, 15, 383-389.

Zanirati, D. F. (2012). Caracterização de bactérias láticas da microbiota de grãos de Kefir cultivados em leite ou água com açúcar mascavo por metodologias dependentes e independentes de cultivos. Dissertação de Mestrado em Biologia Geral. Belo Horizonte: Universidade Federal de Minas 